duties at the capital. With the completion of the equipment of the little Observatory at Washington, he, however, formally resigned, on April 30, the Directorship at Allegheny, which he had held since I 887 ; and he will, so far as his administrative occupations permit, give personal attention to the general direction of the investigations.

The class of work which is referred to does not ordinarily involve the use of the telescope, and that which is contemplated is quite distinct from what is carried on at present at any other Observatory in the United States. The work for which the older Government Observatories at Greenwich, Paris, Berlin, and Washington were founded, and in which they are now chiefly engaged, is the determination of relative positions of heavenly bodies, and our own place with reference to them. Within the past twenty years all these Governments, except that of the United States, have established astrophysicai Observatories, as they are called, which are, as is well known, engaged in the study of the heavenly bodies as distinct from their positions-in determining, for instance, not where, but what, the sun is, how it affects terrestrial climate and life, and how it may best be studied for the purposes of the meteorologist, and for other uses of an immediately practical nature.

The new Observatory is established for similar purposes. Its outfit includes a very large siderostat (recently completed by Grubb), which is mounted in such a way as to throw a beam of light horizontally in the meridian. It is intended to carry a mirror of 20 inches diameter, and is perhaps the most massive and powerful instrument of its kind ever constructed Within the dark room is mounted another large instrument-the spectrobolometer - which is, in effect, a large spectroscope with 20 -inch circle reading to 5 seconds of arc, specially designed for use with the bolometer. It was made by William Grunow and Son, of New York, as the outcome of Mr. Langley's experience with smaller apparatus during his earlier investigations. The most important part of the instrumental equipment is completed by specially designed galvanometers, scales, and a peculiar resistance box; and these three instruments, used in conjunction with the bolometer, and perhaps with the aid of photography, will be employed in the investigations upon light, heat, and radiant energy in general, for which the Observatory is primarily intended, though some departments of terrestrial physics may also receive attention.

\section{THE NEW GALLERY OF BRITISH ART.}

W

believe that the Committee appointed by the Corporation to consider the question of the grant of a site on the Embankment for the new gallery will soon make its report. The Pall Mall Gazette of Tuesday says :- "There is a vacant piece of just one acre at Blackfriars, on the land acquired some years ago and cleared of the old City gas-works by the Corporation. This land originally cost some $£ 260,000$; and on portions of it have been erected the City of London School and Sion College. The value of the entire holding has increased to at least $£ 550,000$; so that if the proposed piece, which is valued at about $£ \mathrm{I} 20,000$, were made over by the Corporation for the Art Gallery, the City would still be a gainer of some $£ 170,000$ by the transaction."

In the meantime, public opinion is rapidly growing, not only in favour of some of our national buildings devoted to art finding a home in the City, but also against the site at South Kensington-bought for scientific purposes, and required to meet existing needs-being diverted from its proper and natural use.

Both these views are expressed in the following Memorial, which, although circulated chiefly among NO. I I 33 , VOL. 44$]$ men of science during the last few days, contains the names of many representative men in other branches. It has been transmitted to the Lord Mayor during the present week.

\section{Memorial to the Right Honourable the Lord Mayor of London.}

WE, the undersigned, having heard that there is a possibility of the City of London finding a site on the Embankment for the National Gallery of British Art, which a munificent donor has proposed to build, venture to approach Your Lordship with our earnest request that you will yourself support, and use your best endeavours to urge upon the City authorities, the very great importance of giving effect to this proposal.

The memorial already presented to the Prime Minister will have made Your Lordship aware of the many strong objections, from the scientific point of view, to the site which was suggested for the gallery in the first instance.

It is unnecessary for us, therefore, to say more on this subject, except to remark that the greatest city in the world must be the first to suffer if, from any cause, the proper presentation of science and means for its study by its citizens are in any way crippled.

By affording a site on the Embankment, Your Lordship and the authorities you represent will be the means of preventing the lamentable result to which we have referred, and you and they will earn the gratitude of all interested in scientific progress, as well as confer a great boon on the art-loving public.

Among the signatories of the Memorial are the following:-

Sir Villiam Thomson, D.C.L., LL.D., President Royal Society, Professor of Natural Philosophy, Glasgow.

DR. John Evans, LL.D., F.R.S., Treasurer Royal Society.

LORD RAYLEIGH, F.R.S., Secretary Royal Society.

M. Foster, M.D., F.R.S., Secretary Roval Society.

Thomas H. HuxLey, F.R.S., Dean of the Royal College of Science, London.

Lieut.-General R. Strachey, F.R.S., C.I.E., Chairman Meteorological Council.

Nevil, Story MaSkelyne, F.R.S., M.P., Professor of Mineralogy, University of Oxford.

SiR JoHN LubBOCk, Bart., M.P., F.R.S., Chairman London County Council, Past-President British Association.

Sir Richard Quain, Bart., M.D., F.R.S.

Sir William Roberts, F.R.S., M.D.

Wili.Iam Crookes, F.R.S., President Institute Electrical Engineers.

William Summers, M.P.

J. W. L. Glaisher, M.A., F.R.S.

AlfRED NEWTON, F.R.S., Professor of Zoology, University of Cambridge.

T. E. THORPE, F.R.S., Professor of Chemistry, Royal College of Science, Treasurer Chemical Society.

John W. JudD, F.R.S., Professor of Geology, Royal College of Science.

William Huggins, D.C.L., F.R.S., President-Elect of the British Association.

Sir G. G. Stokes, Bart., M.P., Past-President Royal Society, Lucasian Professor, University of Cambridge.

Sir Henry E. Roscoe, LL.D., F.R.S., M.P., Past-President British Association.

W. Grylls Adams, F.R.S., Professor of Physics, King's College, Past-President Physical Society.

J. Fletcher Moulton, Q.C., F.R.S.

E. A. SCHÄFER, F.R.S., Professor of Physiology, University College, London.

Herbert MCLeod, F.R.S., Professor of Chemistry, Cooper's Hill.

Hugo Müller, F.R.S., Past-President Chemical Society.

Arthur W. RüCker, F.R.S., Professor of Physics, Royal College of Science, London, Treasurer Physical Society.

William CaWthorne Unwin, F.R.S., Professor of Engineering, City and Guilds of London Institute.

W. E, AYRTON, F.R.S., Professor of Physics, City and Guilds of London Institute, President Physical Society. 
O. Henricr, F. R.S., Professor of Mathematics, City and Guilds of London Institute.

Henry E. Armstrong, F.R.S., Professor of Chemistry, City and Guilds of London Institute, Secretary Chemical Society.

R. B. Clifton, M.A., F.R.S., Professor of Natural Philosophy, University of Oxford.

J. Burdon Sanderson, F.R.S., Professor of Physiology, Oxford.

William Odling, F.R.S., Professor of Chemistry, Oxford.

William EsSON, F.R.S., Oxford.

EDWARD B. POULTON, F.R.S., Oxford.

E. Ray Lankester, F.R.S., Deputy Professor of Anatomy, Oxford.

G. Carey Foster, F.R.S., Professor of Physics, University College, London ; Past President Physical Society.

J. Hopkinson, F.R.S., Wheatstone Professor of Electricity, King's College, London.

CAPTAIN ABNey, C.B., F.R.S.

The Very Rev. G. G. Bradley, D.D., C.B., Dean of Westminster.

WILI.IAM BLACK.

LEWIS MORRIS.

W. H. M. Christie, F.R.S., Astronomer-Royal.

WILLIAM MORRIS.

WaLter Crane.

W. J. Russell, F.R.S., Professor of Chemistry, St. Bartholomew's Hospital, Past-President Chemical Society.

The Lord Tennyson, F.R.S., Poet Laureate.

Hallam Tennyson.

\section{CARDINAL HAYNALD.}

$\mathrm{T}$ $\mathrm{HE}$ death of Cardinal Haynald, Archbishop of Kalocsa, is announced in the daily papers as having taken place on Saturday, the $4^{\text {th }}$ inst. It was not an unexpected event, as his health had been gradually getting worse for some two or three years. Last year he celebrated the jubilee of his priesthood, and Dr. A. Kanitz, Professor of Botany in the University of Klausenburg, made it the occasion of publishing a eulogy on him as a botanist. This was translated into French by Prof. E. Martens, of Louvain. Although an excellent botanist, Cardinal Haynald was better known as a patron of botany than as a contributor to botanical literature. For the following particulars of his life and work we are mainly indebted to Dr. Kanitz's memoir.

Cardinal Haynald was born about I8I6. His taste for botany was inherited from his father, who himself possessed a fine herbarium. During his stay at Vienna, in the Augustinæum, a theological college, he became acquainted with Edward Fenzl, then assistant curator of the botanical department of the Court, under whose tuition his botanical studies took a more practical shape. His priestly duties, however, did not allow him to follow his favourite study until he was appointed Bishop of Transylvania, when he began to investigate the flora of this country with indefatigable zeal. $\mathrm{He}$ became Archbishop of Karthago, and afterwards of Kalocsa, and after the accession of Leo the Tenth to the Papal chair, a Cardinal. He was a long time a prominent member of the Hungarian House of Magnates, and from 1873 also a member of the Royal Hungarian Academy of Science. Although always overburdened by the sacerdotal, political, and social duties of his high position, he found time to continue his botanical studies. He published only a few botanical papers, partly on Hungarian plants, and partly biographical sketches of botanists with whom he was more intimately acquainted, as Fenzl, Parlatore, and Boissier. His greatest merit, however, from a scientific point of view, was the assistance which he gave to botanical studies in Hungary by establishing a great private herbarium, which he placed in the most liberal way at anybody's disposal, and by the magnanimous generosity with which he always supported botanical enterprise, both in Hungary and abroad. The herbarium at his residence at Kalocsa was not only the richest in Hungary, but one of the largest private collections on the Continent. It was largely formed by the purchase of the herbaria of Heuffel, Schott, Kotschy, and Sodiro. Besides these and the plants collected by himself, he acquired most of the collections which have been distributed by subscription.

Hungary loses in Cardinal Haynald one of her greatest patriots, who was an honour to his profession, as well as to science, of which he was always a generous benefactor. Schur named after him a genus of grasses, founded on Secale villosum, Linn., which is reduced by Bentham and Hooker to Agropyrum, and Kanitz a genus of Lobeliaceæ.

\section{OXFORD SUMMER MEETING OF UNIVERSITY EXTENSION STUDENTS.}

THE process by which University Extension is carried throughout the country and made a vehicle for the further education of the adult student is well known, and is gradually becoming more and more appreciated in proportion as those who are responsible for the method improve the lines on which it is carried out. The machinery employed embraces lectures, classes, travelling libraries, \&c., but one element vitally necessary to the University student is not supplied by these aids. This element is that of residence, and it was a happy suggestion on the part of the originators to propose that, for one month in the Long Vacation, arrangements should be made by which those who have profited by being brought into contact with a University lecturer should enjoy the additional advantage of being brought under the charm that haunts the colleges and cloisters of Oxford and Cambridge.

The Oxford summer meeting commences on July $3 \mathrm{I}$, and is continued throughout the month of August; but, for the benefit of students who are unable to be present. during so long a period, the course is divided into two sections, the second commencing on August I2. It has been found desirable to remove as far as possible the fragmentary and isolated character of the lectures given at these meetings, and therefore, while the course will be complete and independent in itself, it will also form the first part of a cycle of study which for its full development will embrace a period of four summers.

That these lectures propose something more than to add piquancy to an agreeable picnic will be shown from the following slight sketch of the subjects treated-and treated by authorities of acknowledged reputation. To take the lectures on natural science first: in physiology, $\mathrm{Mr}$. Poulton will discuss the recent criticisms of Weismann's theory of heredity, and Mr. Gotch will lecture on the functions of the heart. In chemistry, Prof. Odling lectures on the benzene ring, and under the supervision of Mr. Marsh a course of practical chemistry will be conducted in the laboratory of the University Museum. In geology, a course of practical instruction will be given by Prof. Green and Mr. Badger, to include excursions in the neighbourhood of Oxford. A class in practical astronomy will be welcomed at the University Observatory; while electricity finds an able exponent in Mr. G. J. Burch. But the distinguishing feature of this meeting is the attention given to agricultural science "designed for agricultural audiences under County Council schemes." This designation seems somewhat vague, and it will be very interesting to see the character of the audience attracted by this title. Four lectures are offered : the first is entitled, "The application of Science to the art of Agriculture." This description is sufficiently wide, but does not indicate whether the lecture is intended as a sample of those which State-aided Board No. I I 33 , vor. 44] 